\title{
The Strategic Responses from Sophisticated Investors to Inaccurate Forecast of Financial Analysts
}

\author{
Dr. Kuo-Hao Lee ${ }^{1}$, Dr. Loreen M. Powell ${ }^{2}$, Dr. Lam Nguyen ${ }^{3} \&$ Dr. Evren Eryilmaz ${ }^{4}$ \\ ${ }^{1}$ Department of Finance, Zeigler College of Business, Bloomsburg University of Pennsylvania, 400 E. Second St., \\ Bloomsburg, PA 17815-1301, USA \\ ${ }^{2}$ Department of Innovation, Technology, and Supply Chain Management, Zeigler College of Businessm Bloomsburg \\ University of Pennsylvania, USA \\ ${ }^{3}$ Department of Management and International Business, Zeigler College of Business, Bloomsburg University of \\ Pennsylvania, USA \\ ${ }^{4}$ Department of Management Information Systems, College of Business, California State University Sacramento, \\ USA
}

Correspondence: Dr. Kuo-Hao Lee, Department of Finance, Zeigler College of Business, Bloomsburg University of Pennsylvania, 400 E. Second St., Bloomsburg, PA 17815-1301, USA

Received: October 2, 2017

Accepted: October 30, 2017

Online Published: February 1, 2018

doi:10.5430/afr.v7n1p272

URL: https://doi.org/10.5430/afr.v7n1p272

\begin{abstract}
We examine whether there are more information based trading activities that are generated around the time of earnings announcements. We distinguish between the influence of information based traders, especially short sellers, and market information quality through the reaction of participants to new information derived from corporate earnings announcements. We find that informed traders do take advantage of overpriced stocks, and do short stocks before the confirmation of past expectations of future cash flows from corporates. We apply Standardized Unexpected Earnings (SUE) in the method and our result indicates that informed traders are more likely to take advantage of overpriced stocks, using a tool (shorting) that is not traditionally used by unsophisticated investors. We also demonstrate an unique finding that informed traders follow stock analysts not for investing advice, but to take advantage of those unsophisticated investors that buy in to the rhetoric expressed by financial analysts.
\end{abstract}

Keywords: Informed trader, Earnings Announcements, SUE, Analysts Errors

\section{Introduction}

Financial analysts have very critical roles in the stock market in the sense that they act as a connecting bridge of information, transferring information between firms and investors. Financial forecasting reports from specialized financial analysts are highly referenced materials for investors; many investors believe that these reports help them make informed investment decisions.

Information based traders rely heavily on professional forecasting of financial numbers from financial analysts - as analyst reports influence the decision making of information based traders. Forecasting errors will have different effects on different grades of investors; those with advanced information or, better, a superior ability to interpret more accurate results than normal public investors will see thru the inaccuracy and invest accordingly. We believe that this superior knowledge will lead to a noticeably different trading behavior by market participants, wherein we could find both abnormal trading volume and abnormal returns before the earnings announcements from the transactions they make. Investors with advanced information could intuitively untangle the accuracy level of financial analysts' forecast reports on corporate earnings since they do have this superior knowledge. When analysts/forecasters make serious mistakes in forecasting financial reports, informed traders should have the ability to seize on the opportunity modify the transaction activities before earnings announcements - ahead of other non-informed investors. If the analysts make a negative forecast error, where the actual earnings number was smaller than the forecasted one, informed trading (in the form of shorting activity), should significantly increase trading volume before earnings announcement. These changes will eventually be revealed post announcement day after the selloff ensues when short sellers cover their short positions. 
By using the events of earnings announcement, we could empirically examine whether there are more information based trading activities that are generated around the time of earnings announcements; this methodology is in line with prior studies. Moreover, we can further distinguish between the influence of information based traders, especially short sellers, and market information quality through the reaction of participants to new information derived from corporate earnings announcements.

\section{Literature Review}

News about macro and micro related data has the greatest tendencies to drive stock returns and increase volatility. Research has shown that investor sentiment is the main driver of these changes in return and volatility, and that expectation differentials drive prices to either overreact or underreact (Bloomfield and Hales, 2002; Daniel, Hirshleifer, and Subrahmanyam, 2001; Montier, 2002; Poteshman, 2001; Theobald and Yallup, 2004; Thomson et $\mathrm{al}, 2003)$. Other research in the over-reaction and under-reaction of stocks theory rely on momentum of stock return trends, where sentimental investors participate in what is known as herding/crowd/flock behavior. This behavior is based on the notion that investors follow others under the assumption that the "leader" has asymmetric information that is not available to others (Kang, Liu, and Ni, 2002; Brunnermeier, 2001). Once news becomes public and information becomes symmetrical there is often an adjustment to returns and a subsequent increase in volatility based on differentials between investor expectations and actuality. Eventually, symmetrical information leads to true price discovery and a subsequent decrease in volatility.

The traditional method of measuring market efficiency is through an event study. This methodology entails monitoring the abnormal movement of the value of an arbitrary variable before, at, and after the onset of an event. The methodology, in the form of a regression, seeks to find if the changes in the value of the arbitrary variable incur abnormal change before, during, and after the event occurs, and whether these changes are significant or not (MacKinlay, 1997).

Market efficiency and irrationality are both rooted in the premise of trading on fundamentals. Efficiency claims that all movements in the market are substantiated, while irrationality claims that movements are exaggerated. It is important to note, however, that market participants share the same goal of profit maximization. Given that all participants in the market share this particular goal, any movement upwards or downwards in a stock price must be associated with an investor sentiment of either an increase or decrease, respectively, of the underlying value of the asset.

The Technical Committee of the International Organization of Securities Commissions (IOSCO, 2008) claims that short sellers provide efficiency in asset markets as mechanisms to calibrate price discovery and subsequently reduce the chance of a bubble in stock markets. Moreover, short sellers could improve the liquidity of the markets. Boehmer, Jones, and Zhang (2008) also found that short sellers provided significant liquidity to the markets. Lecce, et al (2012) have a slightly different point of view, where they used volatility, bid-ask spreads, and trading volume to demonstrate that naked short sales will lower market efficiency. They further claim that naked short sellers do not make price discovery more efficient. Generally, prior studies show that the market activities from short sellers could improve the efficiency of the market and increase the speed of true price discovery.

There is a large amount of prior research that look at the high correlations between short sales and asset returns; for example Chen et al. (2002), Nagel (2005), D'Avolio (2002), Cohen et al. (2007), Jones and Lamont (2002), and Asquith et al. (2005) are studies that were focused on empirically testing the high correlation of short sales and stock returns. Accordingly, based on prior studies, other papers also discussed the shorting activities from either the short supply or demand side perspective. They looked into the correlation between short sales and returns. Furthermore, these literatures all indicated that institutional investors acted as the important function of supplier to the shorting activities in the market. Takahashi (2010) indicated that the higher the cost of adverse choice the higher earnings short sellers will earn from a negative stock price movement; this implied that short sales were informed trading. He also found that short sellers not only acted as informed investors, who gained from negative information, but they were also skillful investors who detected stock price deviations from fundamental values.

Past studies have found that short sale trading is highly correlated with negative returns of the underlying stock price (reversion downwards to the fundamental stock price). Therefore, if there is a high correlation between short sellers and a downwards movement of stock prices towards fundamental prices then we can use short selling activities as proxies to detect the presence of informed traders.

During short selling operations, short sellers rely on the ability to sell stocks that they do not own. To perform this operation, they could either borrow stocks from others to sell, or sell stocks that they do not have (i.e. naked short 
selling). Short selling involves several constraints, the first constraint, the most obvious, is not being able to borrow the underlying stock in order to perform the short sale; basically a supply side argument. Other prior studies use different proxy variables for modeling the supply side and have found similar results. Chen et al. (2002) use the breadth of stock holdings of mutual funds to test this constraint. Nagel (2005) applied the condition of institutional holdings, and D'Avolio (2002), Cohen et al. (2007), and Jones and Lamont (2002) used cost of short sales markets to examine the relationship between the supply side of proxy variables and stock price. The second constraint is the actual cost of short selling; short selling involves several indirect costs such as interest payments on stocks being borrowed.

According to current mainstream financial theories, informed short sellers are usually assumed to be more rational and experienced than most other investors. For instance, Asquith et al. (2005) distinguish between demand and supply in the markets and represent these interests as institutional and short interests respectively, they find that short sellers are constrained when there is strong demand, and vice versa. Cohen et al. (2007) found that the number of short sales contract could be used to predict stock returns, and short sellers generally have a greater influence on a downward movement in the stock price if the firm of the underlying stock was a small-cap firm. However, findings from previous studies effectively substantiated these claims but have come up with a different reason why this happens confirmed the research topic in different conclusion. Lamont and Stein (2004) look at the relationship between the number of short sales contracts, and stock price, and found that they were not consistent with others' arguments. Diether, Lee, and Werner (2009) found that by constructing the liquidity based short sales demand variables, stock returns had a significantly higher negative correlation. Their finding supported the argument of a highly negative correlation between short sale demand and stock returns. Boehmer, Jones, and Zhang (2008) found that the institutional investors were involved in large amounts of short sale transactions in the market.

When the market is inopportune for short sale activities or if there are short sale constrains restricting or preventing shorting, short sale transactions will suffer. However, if investors could apply the derivatives market to act as complements to their shorting objectives (such as selling a call or buying a put) then the short selling can still be emulated. Therefore, information from derivatives markets or other alternative financial products markets can be used as proxies to short selling activities. The question of whether or not the information from these alternative financial markets could be used as a new source to predict the price in stock market has become a major research issue in academia, especially during periods of financial crisis.

Black (1975) and Manaster and Rendleman (1982) found that exchange traded options were alternative ways to directly fulfill investment objectives with substantially lower costs. Back (1993) and Biais and Hillion (1994) pointed out that option prices emulate stock prices, investors could have a higher leverage usage of every dollar they put into the option market as opposed with the stock market. Therefore, private information that could have been revealed when stock prices move, can therefore be reflected covertly in options instead. This information communication mechanism should also eliminate the potential for arbitrage opportunity. Skinner (1990) observed the relationship of the launch of stock options and the reaction of stock price through the event of the retain earnings announcement. He found that the reaction of stock prices to the announcement of retain earning was stronger post-entry in to the derivatives market than pre-entry. Roll, Schwartz and Subrahmanyam (2010) argue that the launch of stock option to the market means informed traders could put to better use their private information.

Prior researches on whether experienced investors, such like institutional investors and short sellers, could gain abnormal return based on the trading skill through purchases or sales of stock-picking ability. Gruber (1996), and Wermers (2000) found that institutional investors are informed traders just by observing their trading behavior. Desai, Ramesh, Thiagarajan and Balachandran (2002), Jones and Lamont (2002), Asquith, Pathak and Ritter (2005), Boehme, Danielsen and Sorescu (2006), Diether, Lee and Werner (2009) and Boehmer, Jones and Zhang (2008) analyzed the behavior of short seller's trading activities and recognized that the transactions from short sellers were based on informed trading.

\section{Methodology}

We would like to see how stocks that have different characteristics, as discussed earlier, react pre and post earnings announcement. In order to model the reactions of these stocks, we perform an event study. In our sample we use 416 S\&P-500 listed firms as our research target. In order to comply with the event study's design the following will be considered:

1. Whether the Standardized Unexpected Earnings (SUE, Sadka (2006)) was positive or negative.

2. Whether the Analyst Forecast Error was positive or negative. 
3. Whether the stocks had complementary derivatives (single stock futures) product being traded in the market.

The main reason that we decided to make these three considerations was that, based on the results of previous studies, these three characteristics have a strong influence on the outcome of an earnings announcement. Furthermore, we expect that these characteristics will have a greater implication in our study.

We apply our research to the 416 S\&P-500 listed firms that have their fourth quarter earnings announcements of 2010 on December $31^{\text {st }}$ for our research. The reason why we choose these stocks and the same day is because: (1) Choosing the same day of announcement for our entire sample allows us to discount other influences on volatility and returns. (2) By being listed on the index, S\&P-500 firms must comply with uniform standards required by Standard and Poor's in addition to other standards required by the government. Our study differentiates itself from previous studies because we choose to use only S\&P-500 listed big cap stocks with corresponding derivatives products, as previous studies choose non-big cap stocks to compare. The problem with choosing non-big cap stocks, as with previous studies, is that smaller firms sometimes do not have the resources to efficiently and accurately disclose information to the public.

For our event window, we use twenty days before and after (from 12/2/2010 to 1/31/2011) the corporate earnings announcement event (12/31/2010). We used non-Reg SHO listed stocks as of that day. The data was from various sources due to the complexities required by the research design. We downloaded basic quarterly corporate financial reports from the Compustat database, daily stock short sale trading data was compiled from BATS database, analysts' forecasting data was compiled from Institutional Brokers' Estimate System (I/B/E/S), and information regarding the Fama and French three factor model information was obtained from Fama and French's website (http://mba.tuck.dartmouth.edu/pages/faculty/ken.french/).

In our study we will consider, based on analysis of previous studies, that short sellers are informed traders. We solely consider both short sellers and institutional investor as informed traders but our analysis considers only short sellers, as we can only obtain daily information on short selling activities. Institutional investor activities are provided, but only quarterly; therefore, for the purpose of our study, we will only consider short sellers as informed traders.

Investors by nature are forward looking, i.e. investors invest based on expectations of future cash flows, but expectations of future cash flows are also based on past performance. Investors extrapolate the expectations of future performance based on past performance. Investors, as noted in almost all earnings announcements, look at percentage increases in cash flows to base the price of a firm's asset. Therefore, it is fitting that we model or research to consider benchmark stock prices as a proxy for past earnings increases in cash flow as a function of dividends (or earnings per share (EPS)). We apply Standardized Unexpected Earnings (SUE) to estimate earnings surprises.

When actual earnings is eventually revealed during the quarterly earnings announcements, the revelation can either be one of three things, above consensus estimates, below consensus estimates, or in line with consensus estimates. The differentials between what the consensus is and what is actually revealed will be defined hereinafter as Unexpected Earning (UE):

$$
U E_{i}=E P S_{i, q}-E P S_{i, q-4}
$$

Where EPSi,q was the end of year earnings per share reported in the financial statements for stock $\mathrm{i}$, in year $\mathrm{n}$; EPSi,q-4 was earnings for the fourth quarter of stock $i$, in year $n-1$. We further calculated the standard deviation $(\sigma)$ of unexpected earnings over the preceding eight quarters to Standardize Unexpected Earnings (SUE):

$$
\begin{array}{r}
S U E_{i}=\frac{E P S_{i, q}-E P S_{i, q-4}}{\sigma_{E P S_{i, q}-E P S_{i, q-4}}} \\
\sigma_{E P S_{i, q}-E P S_{i, q-4}}=\sqrt{\frac{\sum_{n=q-8}^{q-1}\left[\left(E P S_{i, n}-E P S_{i, n-4}\right)-\overline{\left(E P S_{i, q}-E P S_{i, q-4}\right)}\right]^{2}}{8}} \\
\frac{\sum_{n=q-8}^{q-1} E P S_{i, n}-E P S_{i, n-4}}{8}
\end{array}
$$


The formula above was the estimation method of reporting UE extracted from previous literature. However, we consider trends in UE, therefore we refer to the method of estimation of SUE used in Sadka (2006).

$$
\begin{gathered}
S U E_{i}=\frac{E P S_{i, q}-E P S_{i, q-4}-c_{i}}{\sigma_{E P S_{i, q}-E P S_{i, q-4}}} \\
c_{i}=\overline{\left(E P S_{i, q}-E P S_{i, q-4}\right)}=\frac{\sum_{n=q-8}^{q-1} E P S_{i, n}-E P S_{i, n-4}}{8}
\end{gathered}
$$

We consider the seasonal random walk through the use of a trend variable. The trend variable or "drift term" is added to comply with Bernard and Thomas $(1989,1990)$ and Ball and Bartov (1996). In order to categorize the earnings announcements in three different ways, (1) positive (earnings was above its trend), (2) neutral (earnings was in line with its trend), and (3) negative (earnings was below its tend).

To obtain analyst forecast error, we applied the same formulas mentioned above, but we replace the $\mathrm{EPS}_{\mathrm{q}-4}$ by the analysts' predicted EPS to compute the analyst forecast error,

$$
S U E A_{i}=\frac{E S P_{i, q}-E S P A_{i, q}-c_{i}}{\sigma_{i, E S P_{i, q}-E S P A_{i, q}}}
$$

Where EPSA represents the analyst forecast by means of EPS that was predicted by the analyst for stock i for the same announcement quarter.

We applied Fama and French (1993) three factor model to estimate the stocks' abnormal returns. Fama and French (1993) three factor model is listed below:

$$
R_{i, t}=\alpha+\beta_{M K T} M K T_{i, t}+\beta_{S M B} S M B_{i, t}+\beta_{H M L} H M L_{i, t}+\varepsilon_{i, t}
$$

Where R is stock returns, MKT was the market risk free interest rate; SMB stands for returns of portfolio of small market capitalization minus big market capitalization firms; HML stands for high book-to-market ratio portfolio returns minus low book-to-market ratio portfolio returns. The variables $\alpha$ and $\beta$ are regression coefficients, and $\varepsilon$ is the error term. The estimation of coefficients will be obtained by the Fama and French (1993) three factor model over our period (60 days prior to the event period). Then, we replaced the coefficients into the Fama and French (1993) three factor model to compute the error term over the event period, which we define the difference between these two as abnormal returns.

$$
A R_{i, t}=R_{i, t}-\left(\hat{\alpha}+\hat{\beta}_{M K T} M K T_{i, t}+\hat{\beta}_{S M B} S M B_{i, t}+\hat{\beta}_{H M L} H M L_{i, t}\right)
$$

The intention of this paper is to test for the presence of informed traders; therefore, we need a proxy for informed traders as it would be nearly impossible to accurately survey sellers on their knowledge of individual stocks. We will investigate this through high trade volume periods, which are traditionally right before and after earnings announcements events. If informed traders are more sophisticated in pinpointing the fundamental price of the underlying asset, they naturally have an advantage over normal public investors if these normal public investors are mispricing the asset. If the earnings announcements numbers have a large gap between expected numbers and the actual earnings numbers, e.g. a huge prediction error, then informed traders would be more tempted to trade the stock any which way they believed to be towards the fundamental price (e.g. if the stock was overpriced they would sell) before the announcement periods of corporate earnings. Therefore, this huge differential will lead to a high correlation between informed trading and stock price.

We will adopt the method used in Takahashi (2010) to estimate the short side of informed trading; the proxy variables of short sales demand would be done through calculating the ratio of incremental short sales to trading volume. We refer to the definition of abnormal short selling (ASS), as referenced in Christophe, Ferri, and Angel (2004) and Henry and Koski (2010) to observe and calculate abnormal short selling below:

$$
A S S_{t}=\frac{T S S V_{t}}{A D S S V_{t}}-1
$$


Where TSSV is the daily total short selling volume of the stock and ADSSV stands for the average daily short selling volume.

$$
\operatorname{ADSSV}_{t}=\frac{\sum_{n=t-20}^{t} T S S V_{n}}{\sum_{n=t-20}^{t} D_{n}}
$$

Where $D_{n}$ is 1 if $\operatorname{TSSV}_{n} \neq 0$; otherwise, $D_{n}$ is 0 .

Due to the reason that the abnormal short selling volume would be changing by the transaction volume of abnormal trading, therefore, daily abnormal trading volume (AVol) would be:

$$
A \operatorname{Vol}_{t}=\frac{\text { Vol }_{t}}{M \operatorname{Mol}_{t}}-1
$$

Where Vol is the total daily trading volume for the stock; MVol stands for the average daily trading volume.

$$
\mathrm{MVol}_{t}=\frac{\sum_{n=t-20}^{t} \operatorname{Vol}_{n}}{\sum_{n=t-20}^{t} D_{n}}
$$

Where $D_{n}$ is 1 if $\operatorname{Vol}_{n} \neq 0$; otherwise, $D_{n}$ is 0 .

Just as the notion said in Henry and Koski (2010), we also considered that the increased abnormal short selling trading volume might be caused by the increased volume of abnormal trading activities. For that reason, the disproportionate raise in the rate of abnormal short selling volume to abnormal trading volume would be a better representative of information from short sellers. Hence, we further calculate the abnormal relative short selling (ARSS):

$$
A R S S_{t}=\frac{\left(1+A S S_{t}\right)}{\left(1+A V o l_{t}\right)}-1
$$

Our objective is to make an integrated and holistic view of the entire market and its influences on each and every underlying stock, therefore, we look at informed trading purely from the demand side point of view, and we further integrate the inclusion of each stock in the derivatives markets. We are particularly eager on find a proxy variable that could accurately reflect the abnormal returns of the underlying stock to the stock markets, especially for short selling activities; therefore, we adopt a modified event study method for the research.

The event windows for our research are listed below:

Table 1. Event windows for our research

\begin{tabular}{lll}
$\begin{array}{l}\text { Accumulated Abnormal Trading } \\
\text { windows: }\end{array}$ & $\begin{array}{l}\text { (CSS) event } \\
\text { Accumulated Abnormal Return (CAR) event } \\
\text { windows: }\end{array}$ \\
\hline $\mathbf{5}$ day intervals: & $\mathbf{5}$ day intervals: \\
\hline $\mathbf{( - 2 0 , - 1 6 ) , ( - 1 5 , - 1 1 ) , ( - 1 0 , - 6 ) , ( - 5 , - 1 )}$ & $\begin{array}{l}(-15,-11),(-10,-6),(-5,-1),(0,4),(5,9),(10,14), \\
(15,19)\end{array}$
\end{tabular}

We estimate abnormal returns in our regression model by adopting the Fama and French three factor model. The Fama and French three factor models have already controlled for firm characteristics; therefore, we only have to simply carry out the test between two variables in the regression. The cross sectional regression model we are going to use will be:

$$
\operatorname{CSS}\left(t_{1}, t_{2}\right)=\alpha+\beta_{1} \operatorname{CAR}\left(t_{3}, t_{4}\right)+\beta_{2} \operatorname{CAR}\left(t_{5}, t_{6}\right)+\beta_{3} \operatorname{CAR}\left(t_{7}, t_{8}\right)+\varepsilon
$$

Where $\mathrm{t}_{1} \leq \mathrm{t}_{3}$ and $\mathrm{t}_{3}<\mathrm{t}_{4}<\mathrm{t}_{5}<\mathrm{t}_{6}<\mathrm{t}_{7}<\mathrm{t}_{8}$

$$
\begin{gathered}
C S S\left(t_{1}, t_{2}\right)=\sum_{t=t_{1}}^{t_{2}} \operatorname{ARSS}_{t} \\
\operatorname{CAR}\left(t_{1}, t_{2}\right)=\sum_{t=t_{1}}^{t_{2}} A R_{t}
\end{gathered}
$$


CSS is the accumulated abnormal short sales variable, CAR is the accumulated abnormal returns, $\left(\mathrm{t}_{\mathrm{i}}, \mathrm{t}_{\mathrm{j}}\right)$ is the event window. We then can study the relationship of the proxy variable of informed trading and abnormal returns over all combinations of the event windows by observing the coefficients of the three factor model.

We have three main branches laid out to perform our analysis. The first main branch is based on SUE, the second branch is SUEA, and the third is the derivatives based grouping. Taking the first and second branch, we subdivide these groups into three different subgroups (1) Positive SUE, (2) Neutral SUE, and (3) Negative SUE. For all three branches, we perform the analysis using 5 days windows in our analysis using the Fama and French three factor model.

Taking a closer look at our three branches, we can see that stocks that fall in the sub category of positive SUE are stocks that will have a positive surprise upside earnings number at the announcement day which is a number above consensus estimates. Stocks that fall in neutral and negative SUE have numbers that are inline and below consensus estimates respectively. Our research is only focused on the ability for short sellers, as informed traders, to profit from negative SUE's. Accordingly, if we have a negative surprise (if consensus numbers are below consensus estimates) investors would be obligated to sell the underlying asset towards its fundamental price based on the earnings number announced.

\section{Results}

We know that both sophisticated and non-sophisticated investors invest long, but unsophisticated investors seldom invest short. Therefore, if we look both at the long trading side for evidence of abnormality in trading, we would not be able to distinguish between informed and non-informed traders, but if we concentrate on the short side for evidence of abnormality in trading we can safely assume that this abnormality is done by informed trading. Keeping this in mind, when we test for abnormality, if we find that we have a larger amount of abnormal returns with a negative earnings surprise (an earnings announcement below analyst/firm expectations; negative SUE), we can expect that the abnormality came from informed traders.

The following results are for Surprised Unexpected Earnings (SUE):

1. Positive SUE means that we had higher than expected earnings.

2. Neutral SUE means that we had earnings that were in line with expectations.

3. Negative SUE means that we had lower than expected earnings.

In our analysis we had to cover all possible windows of CAR mainly because we have no way of monitoring the behavior of these individual investors. Our results for SUE are shown in the tables below in Table 2 through Table 4. We used "**" to indicate significance at the 0.05 level and "*" to indicate significance at 0.1 level in all the result tables in this study.

Table 2. Negative SUE, Cumulative Abnormal Returns with 5 day event windows

\begin{tabular}{|c|c|c|c|c|c|c|c|}
\hline 5 DAYS EVENT WINDOWS & $\operatorname{CAR}(-15,-11)$ & $\operatorname{CAR}(-10,-6)$ & $\operatorname{CAR}(-5,-1)$ & $\operatorname{CAR}(0,4)$ & $\operatorname{CAR}(5,9)$ & CAR $(10,14)$ & $\operatorname{CAR}(15,19$ \\
\hline \multicolumn{8}{|l|}{$\operatorname{CSS}(-20,-16)$} \\
\hline COEFFICIENTS & -44.80204 & -82.89782 & 52.51466 & 26.94007 & 4.52826 & -66.10500 & -54.41607 \\
\hline P-VALUE & 0.59243 & 0.29078 & 0.70398 & 0.72398 & $0.05281 *$ & 0.30203 & 0.35402 \\
\hline \multicolumn{8}{|l|}{$\operatorname{CSS}(-15,-11)$} \\
\hline COEFFICIENTS & & 0.18747 & 4.35916 & 3.64210 & 2.47254 & 0.75828 & -0.03342 \\
\hline P-VALUE & & 0.94689 & 0.38233 & 0.17914 & $0.03873 * *$ & 0.73349 & 0.98753 \\
\hline \multicolumn{8}{|l|}{$\operatorname{CSS}(-10,-6)$} \\
\hline COEFFICIENTS & & & 4.95361 & 5.24151 & -1.10405 & 2.93014 & 0.87470 \\
\hline P-VALUE & & & 0.33607 & $0.02201 * *$ & 0.71224 & 0.17390 & 0.66811 \\
\hline \multicolumn{8}{|l|}{$\operatorname{CSS} 5(-5,-1)$} \\
\hline COEFFICIENTS & & & & 3.14068 & -1.09417 & 1.45820 & 1.38147 \\
\hline P-VALUE & & & & $0.01961 * *$ & 0.71185 & 0.54602 & 0.53281 \\
\hline
\end{tabular}


Table 3. Neutral SUE, Cumulative Abnormal Returns with 5 day event windows

\begin{tabular}{|c|c|c|c|c|c|c|c|}
\hline 5 DAYS EVENT WINDOWS & $\operatorname{CAR}(-15,-11)$ & $\operatorname{CAR}(-10,-6)$ & $\operatorname{CAR}(-5,-1)$ & $\operatorname{CAR}(0,4)$ & $\operatorname{CAR}(5,9)$ & CAR $(10,14)$ & $\operatorname{CAR}(15,19)$ \\
\hline \multicolumn{8}{|l|}{$\operatorname{CSS}(-20,-16)$} \\
\hline COEFFICIENTS & 1.53843 & 1.58054 & 10.90550 & 0.97783 & -3.26746 & 0.61528 & 4.04905 \\
\hline P-VALUE & 0.60711 & 0.60912 & $0.07458^{*}$ & 0.72408 & 0.45588 & 0.81462 & 0.11045 \\
\hline \multicolumn{8}{|l|}{$\operatorname{CSS}(-15,-11)$} \\
\hline COEFFICIENTS & & -1.72957 & 1.48759 & -1.74417 & 1.13075 & 4.57230 & -1.52996 \\
\hline P-VALUE & & 0.66406 & 0.83481 & 0.61296 & $0.03191 * *$ & 0.13959 & 0.60865 \\
\hline \multicolumn{8}{|l|}{$\operatorname{CSS}(-10,-6)$} \\
\hline COEFFICIENTS & & & 2.69586 & 0.87033 & -5.39613 & -1.36804 & 2.82868 \\
\hline P-VALUE & & & 0.69839 & 0.78226 & 0.27404 & 0.62686 & 0.32649 \\
\hline \multicolumn{8}{|l|}{$\operatorname{CSS} 5(-5,-1)$} \\
\hline COEFFICIENTS & & & & 1.22330 & 0.59988 & 2.54272 & 0.57796 \\
\hline P-VALUE & & & & $0.03613^{* *}$ & 0.89736 & 0.36255 & 0.82929 \\
\hline
\end{tabular}

Table 4. Positive SUE, Cumulative Abnormal Returns with 5 day event windows

\begin{tabular}{l|lllllll}
\hline 5 DAYS EVENT WINDOWS & CAR (-15,-11) & CAR (-10,-6) & CAR(-5,-1) & CAR (0,4) & CAR(5,9) & CAR (10,14) & CAR(15,19) \\
\hline CSS (-20,-16) & & & & & & & \\
COEFFICIENTS & -1.95236 & 0.19685 & 0.92139 & 3.05924 & 1.68990 & 2.24556 & -2.01199 \\
P-VALUE & 0.27726 & 0.95173 & 0.25845 & 0.23497 & $0.08171^{*}$ & 0.35830 & 0.42186 \\
\hline CSS (-15,-11) & & & & & & -1.24249 & 0.34584 \\
COEFFICIENTS & & -0.56605 & 6.04354 & -0.20350 & 2.53427 & 0.87313 \\
P-VALUE & 0.84204 & 0.14354 & 0.92834 & 0.36187 & 0.55520 \\
\hline CSS (-10,-6) & & & & & -1.76847 & 2.80500 \\
COEFFICIENTS & & & -0.57122 & -2.49072 & 4.22455 & 0.17650 \\
P-VALUE & & 0.88957 & 0.25756 & 0.12068 & 0.39301 \\
\hline CSS 5 (-5,-1) & & & & -1.62783 & -3.88968 & 5.23219 & 3.23967 \\
COEFFICIENTS & & & 0.55338 & 0.26239 & 0.64893 & 0.22686
\end{tabular}

As anticipated, looking at CSS/CAR with Negative SUE, as show in Table 2, contain 4 significant instances of abnormal returns. As for CSS/CAR with Neutral SUE, in Table 3, we can see that only three event windows contain significant CSS/CAR. Looking at CSS/CAR with Positive SUE, in Table 4, we can see that we had only one event window that contain significant CSS/CAR.

Comparing Negative SUE ( Table 2) and Positive SUE (Table 4) that we can see that we have more evidence of abnormal returns (negative has 4 instances, and positive has one instance). Further, the coefficients of the Negative SUE are higher than Positive SUE, these results support our hypothesis.

We also consider the effects on stocks covered by analysts. As we mentioned before, unsophisticated investors tend to use analysts for investment purposes, buying on recommendation and selling on downgrades. Therefore, we know if analysts are incorrect in their analysis, informed traders will see this as an opportunity pounce on prices that have been driven up (above fundamental prices) and short the stock in order to gain arbitrage profits. Listed below from Table 5 through Table 7 that showed the results of our cumulative abnormal returns of Standardized Unexpected Earnings by Analysts Error (SUEA) of stocks that are follow by, and exemplified to, the public by analysts. 
Table 5. Negative SUEA, cumulative Abnormal Returns with 5 days events windows

\begin{tabular}{|c|c|c|c|c|c|c|c|}
\hline 5 DAYS EVENT WINDOWS & $\operatorname{CAR}(-15,-11)$ & $\operatorname{CAR}(-10,-6)$ & $\operatorname{CAR}(-5,-1)$ & $\operatorname{CAR}(\mathbf{0 , 4 )}$ & $\operatorname{CAR}(5,9)$ & CAR $(10,14)$ & $\operatorname{CAR}(15,19)$ \\
\hline \multicolumn{8}{|l|}{$\operatorname{CSS}(-20,-16)$} \\
\hline COEFFICIENTS & 3.37504 & -2.11983 & 2.60118 & 12.87702 & -0.61778 & 0.52389 & -0.09336 \\
\hline P-VALUE & 0.31818 & 0.53004 & 0.69667 & $0.00061 * * *$ & 0.87193 & 0.81472 & 0.97131 \\
\hline \multicolumn{8}{|l|}{ CSS $(-15,-11)$} \\
\hline COEFFICIENTS & & -1.86074 & 14.34285 & 0.12311 & 1.06924 & 0.36195 & 0.91257 \\
\hline P-VALUE & & 0.62089 & $0.05511^{*}$ & 0.97642 & 0.81251 & 0.89080 & 0.77049 \\
\hline \multicolumn{8}{|l|}{$\operatorname{CSS}(-10,-6)$} \\
\hline COEFFICIENTS & & & 6.08438 & -0.26087 & -1.96349 & 1.62347 & 5.15277 \\
\hline P-VALUE & & & 0.41689 & 0.94844 & 0.65906 & $0.04729 * *$ & $0.07204^{*}$ \\
\hline \multicolumn{8}{|l|}{$\operatorname{CSS} 5(-5,-1)$} \\
\hline COEFFICIENTS & & & & -3.79024 & 3.23164 & 3.18965 & 4.59161 \\
\hline P-VALUE & & & & 0.40831 & $0.05033 *$ & 0.25846 & 0.16200 \\
\hline
\end{tabular}

Table 6. Neutral SUEA, Cumulative Abnormal Returns with 5 days events windows

\begin{tabular}{|c|c|c|c|c|c|c|c|}
\hline 5 DAYS EVENT WINDOWS & CAR $(-15,-11)$ & CAR $(-10,-6)$ & $\operatorname{CAR}(-5,-1)$ & $\operatorname{CAR}(0,4)$ & $\operatorname{CAR}(5,9)$ & CAR $(10,14)$ & $\operatorname{CAR}(15,19)$ \\
\hline \multicolumn{8}{|l|}{$\operatorname{CSS}(-20,-16)$} \\
\hline COEFFICIENTS & -23.68757 & -106.51068 & 31.26699 & 23.74352 & 42.65526 & -89.82866 & -70.77693 \\
\hline P-VALUE & 0.60999 & 0.16936 & 0.79820 & 0.72130 & 0.60644 & 0.19531 & 0.25852 \\
\hline \multicolumn{8}{|l|}{ CSS $(-15,-11)$} \\
\hline COEFFICIENTS & & -0.72563 & 5.34290 & 0.07574 & 1.20028 & 0.46674 & -1.23635 \\
\hline P-VALUE & & 0.79556 & 0.19180 & 0.97443 & 0.66672 & 0.84020 & 0.55615 \\
\hline \multicolumn{8}{|l|}{$\operatorname{CSS}(-10,-6)$} \\
\hline COEFFICIENTS & & & -1.06730 & -0.31347 & 1.88176 & -1.78945 & 4.12819 \\
\hline P-VALUE & & & 0.78998 & 0.88379 & 0.48521 & 0.40882 & $0.03709^{* *}$ \\
\hline \multicolumn{8}{|l|}{$\operatorname{CSS} 5(-5,-1)$} \\
\hline COEFFICIENTS & & & & 0.78324 & -1.56686 & 5.46194 & 1.54666 \\
\hline P-VALUE & & & & 0.73999 & 0.59359 & $0.02715^{* *}$ & 0.48568 \\
\hline
\end{tabular}

Table 7. Positive SUEA, Cumulative Abnormal Returns with 5 days events windows

\begin{tabular}{|c|c|c|c|c|c|c|c|}
\hline 5 DAYS EVENT WINDOWS & $\operatorname{CAR}(-15,-11)$ & CAR $(-10,-6)$ & $\operatorname{CAR}(-5,-1)$ & CAR $(0,4)$ & $\operatorname{CAR}(5,9)$ & CAR $(10,14)$ & $\operatorname{CAR}(15,19)$ \\
\hline \multicolumn{8}{|l|}{$\operatorname{CSS}(-20,-16)$} \\
\hline COEFFICIENTS & -2.84671 & 1.57001 & 5.21949 & 0.29210 & 3.73812 & 1.42528 & 1.45755 \\
\hline P-VALUE & 0.34134 & 0.56860 & 0.28196 & 0.90072 & 0.23370 & 0.54163 & 0.58171 \\
\hline \multicolumn{8}{|l|}{$\operatorname{CSS}(-15,-11)$} \\
\hline COEFFICIENTS & & 0.24564 & -3.16865 & 0.72720 & -1.78852 & 0.34164 & 0.72665 \\
\hline P-VALUE & & 0.93707 & 0.55269 & 0.77554 & 0.60241 & 0.89247 & 0.79918 \\
\hline \multicolumn{8}{|l|}{$\operatorname{CSS}(-10,-6)$} \\
\hline COEFFICIENTS & & & 2.66551 & 1.60121 & 0.65486 & 0.82116 & -2.05133 \\
\hline P-VALUE & & & 0.62961 & 0.52813 & 0.85271 & 0.74842 & 0.46590 \\
\hline \multicolumn{8}{|l|}{$\operatorname{CSS} 5(-5,-1)$} \\
\hline COEFFICIENTS & & & & 2.99248 & -0.45674 & 2.09778 & 1.32616 \\
\hline P-VALUE & & & & 0.25102 & 0.89553 & 0.41890 & 0.65177 \\
\hline
\end{tabular}


As anticipated, looking at CSS/CAR with Negative SUEA, Table 5, we can see that we had 5 instances of significant cumulative abnormal returns for negative SUEA. Then we checked the results of CSS/CAR with Neutral SUEA, Table 6, we can see that only two event windows contain significant CSS/CAR. On the other hand, CSS/CAR with Positive SUEA, Table 7, we can see that none of the event windows that contain significant CSS/CAR. This result further confirms our hypothesis; informed traders follow analysts not for investment advice, but follow analysts because they know when analysts report wrong expectations, unsophisticated investors will follow their recommendation and buy, sophisticated investors will counteract this, and short.

Per previous studies, we also looked at whether or not the stocks had derivatives products (namely single stock futures). Previous studies have found that informed investors are likely to invest in derivatives of underlying stocks instead of the stocks themselves. Therefore, stocks with complementary derivatives products will have the means to which information could be revealed to non-informed traders. We look at two distinct pairs of stocks, stock with traded single stock futures, and stocks without traded single stock futures.

Our first set of CSS/CAR of stocks without SSF, Table 8 listed below, reveals that there is significant CSS/CAR in the 5days windows. As for CSS/CAR of stocks with SSF, in Table 9, we find that there are two significant CSS/CAR event windows. Moreover, the coefficients of these significant windows are higher for the stocks without SSF.

Table 8. Without SSF, Cumulative Abnormal Returns with 5 days events windows

\begin{tabular}{|c|c|c|c|c|c|c|c|}
\hline 5 DAYS EVENT WINDOWS & $\operatorname{CAR}(-15,-11)$ & $\operatorname{CAR}(-10,-6)$ & $\operatorname{CAR}(-5,-1)$ & $\operatorname{CAR}(0,4)$ & $\operatorname{CAR}(5,9)$ & CAR $(10,14)$ & $\operatorname{CAR}(15,19)$ \\
\hline \multicolumn{8}{|l|}{ CSS $(-20,-16)$} \\
\hline COEFFICIENTS & -15.26339 & -39.68987 & 15.95614 & 5.51309 & 19.09719 & -25.90472 & -23.63837 \\
\hline P-VALUE & 0.53195 & 0.20697 & 0.76927 & 0.84895 & 0.58226 & 0.30749 & 0.34703 \\
\hline \multicolumn{8}{|l|}{ CSS $(-15,-11)$} \\
\hline COEFFICIENTS & & -0.88037 & 4.58007 & 0.70042 & 0.64484 & 0.30033 & 0.06218 \\
\hline P-VALUe & & 0.63184 & 0.13479 & 0.67354 & $0.07419^{*}$ & 0.83266 & 0.96529 \\
\hline \multicolumn{8}{|l|}{ CSS (-10,-6) } \\
\hline COEFFICIENTS & & & 0.63331 & 0.78445 & 0.73865 & 0.60377 & 1.75452 \\
\hline P-VALUe & & & 0.83552 & $0.03616^{* *}$ & 0.69825 & 0.65160 & 0.18932 \\
\hline \multicolumn{8}{|l|}{$\operatorname{CSS} 5(-5,-1)$} \\
\hline COEFFICIENTS & & & & 3.99702 & -0.69599 & 2.95006 & 1.07666 \\
\hline P-VALUE & & & & $0.05385^{*}$ & 0.72024 & $0.03831^{* *}$ & 0.44415 \\
\hline
\end{tabular}

Table 9. With SSF, Cumulative Abnormal Returns with 5 days events windows

\begin{tabular}{|c|c|c|c|c|c|c|c|}
\hline 5 DAYS EVENT WINDOWS & CAR $(-15,-11)$ & CAR $(-10,-6)$ & CAR(-5,-1) & CAR $(0,4)$ & $\operatorname{CAR}(5,9)$ & CAR $(10,14)$ & $\operatorname{CAR}(15,19)$ \\
\hline \multicolumn{8}{|l|}{ CSS $(-20,-16)$} \\
\hline COEFFICIENTS & 2.72310 & -3.72668 & 12.31909 & 1.23123 & 37.04074 & -2.71324 & -0.53221 \\
\hline P-VALUE & 0.75977 & 0.70064 & 0.43893 & $0.05872 *$ & 0.14714 & 0.66827 & 0.90229 \\
\hline \multicolumn{8}{|l|}{ CSS $(-15,-11)$} \\
\hline COEFFICIENTS & & 6.18356 & 2.46539 & 0.94834 & 1.84439 & 9.05552 & 0.99023 \\
\hline P-VALUE & & 0.43540 & 0.84302 & 0.86757 & 0.84190 & 0.17952 & 0.84236 \\
\hline \multicolumn{8}{|l|}{$\operatorname{CSS}(-10,-6)$} \\
\hline COEFFICIENTS & & & 23.99223 & -6.15064 & -7.37914 & -8.80376 & 5.55209 \\
\hline P-VALUE & & & 0.11375 & 0.37872 & 0.52349 & 0.27268 & 0.37007 \\
\hline \multicolumn{8}{|l|}{$\operatorname{CSS} 5(-5,-1)$} \\
\hline COEFFICIENTS & & & & 4.33725 & -3.83606 & -5.98699 & 3.09449 \\
\hline P-VALUE & & & & 0.68487 & $0.07419^{*}$ & 0.64694 & 0.72978 \\
\hline
\end{tabular}


Comparing stocks with SSF to stocks without SSF, we find evidence that stocks without SSF clearly have higher incidents of significant CSS/CAR than do stocks with SSF. This means that stocks that have derivatives products do increase market efficiency. This finding is consistent with current literature claiming to that derivatives increase efficiency by revealing information to participants by others; thereby essentially building an information bridge revealing information about the actions of informed traders to non-informed traders.

To further validate our results, we know that there are some industries to which predicting earnings is much easier than others; e.g. if a company mines silver and sells it on the commodities market, we can see that investors can substantially estimate the total earnings of that company simply by following the commodity market price per ounce of silver [assuming current and expected future production is constant]. Therefore, it is important that we differentiate by industry. Table 10 through Table 19 listed below are the results of CAR of all 10 S\&P 500 industries.

We noticed that Telecommunications Industry has 5 significant event windows and Consumer Discretionary Industry also have 4 significant event windows. And both industries have high coefficients for these significant windows as well. On the contrary, Healthy Care and Utilities Industries have no event windows is showed significant in our results.

Table 10. Energy Industry, Cumulative Abnormal Returns with 5 days events windows

\begin{tabular}{|c|c|c|c|c|c|c|c|}
\hline 5 DAYS EVENT WINDOWS & $\operatorname{CAR}(-15,-11)$ & CAR $(-10,-6)$ & $\operatorname{CAR}(-5,-1)$ & CAR $(0,4)$ & $\operatorname{CAR}(5,9)$ & CAR $(10,14)$ & $\operatorname{CAR}(15,19)$ \\
\hline \multicolumn{8}{|l|}{$\operatorname{CSS}(-20,-16)$} \\
\hline COEFFICIENTS & 4.33645 & -8.25895 & 14.93191 & -5.14695 & 3.59778 & 5.16888 & -1.97346 \\
\hline P-VALUE & 0.40073 & $0.05925^{*}$ & $0.00608 * * *$ & 0.26977 & 0.37418 & 0.12499 & 0.54710 \\
\hline \multicolumn{8}{|l|}{$\operatorname{CSS}(-15,-11)$} \\
\hline COEFFICIENTS & & 1.86767 & 2.77327 & 2.65704 & 0.38627 & -1.19808 & 2.35701 \\
\hline P-VALUE & & 0.70547 & 0.59792 & 0.54568 & 0.91475 & 0.67874 & 0.39933 \\
\hline \multicolumn{8}{|l|}{$\operatorname{CSS}(-10,-6)$} \\
\hline COEFFICIENTS & & & 2.28621 & -1.26342 & -0.01294 & -2.99180 & 4.62531 \\
\hline P-VALUE & & & 0.70092 & 0.76378 & 0.99745 & 0.32011 & 0.11352 \\
\hline \multicolumn{8}{|l|}{$\operatorname{CSS} 5(-5,-1)$} \\
\hline COEFFICIENTS & & & & -0.08841 & -3.35593 & -6.64870 & -1.55578 \\
\hline P-VALUE & & & & 0.98979 & 0.57766 & 0.18462 & 0.75023 \\
\hline
\end{tabular}

Table 11. Materials Industry, Cumulative Abnormal Returns after earnings announcements with 5 days events windows

\begin{tabular}{|c|c|c|c|c|c|c|c|}
\hline 5 DAYS EVENT WINDOWS & $\operatorname{CAR}(-15,-11)$ & $\operatorname{CAR}(-10,-6)$ & $\operatorname{CAR}(-5,-1)$ & CAR $(0,4)$ & $\operatorname{CAR}(5,9)$ & CAR $(10,14)$ & $\operatorname{CAR}(15,19)$ \\
\hline \multicolumn{8}{|l|}{ CSS $(-20,-16)$} \\
\hline COEFFICIENTS & -3.11488 & 2.67933 & 6.89307 & 5.07947 & 7.29149 & 0.52058 & -4.24887 \\
\hline P-VALUE & 0.63153 & 0.65991 & 0.47207 & 0.37165 & 0.28443 & 0.94567 & 0.52206 \\
\hline \multicolumn{8}{|l|}{$\operatorname{CSS}(-15,-11)$} \\
\hline COEFFICIENTS & & -5.58009 & 0.72858 & -5.73129 & -7.90893 & 9.00135 & 1.04420 \\
\hline P-VALUE & & 0.62097 & 0.96012 & 0.57437 & 0.40444 & 0.41304 & $0.08464 *$ \\
\hline \multicolumn{8}{|l|}{$\operatorname{CSS}(-10,-6)$} \\
\hline COEFFICIENTS & & & -5.95775 & -0.83898 & 3.72848 & 6.82408 & 4.89399 \\
\hline P-VALUE & & & 0.63838 & 0.90133 & 0.66789 & 0.44626 & 0.51513 \\
\hline \multicolumn{8}{|l|}{$\operatorname{CSS} 5(-5,-1)$} \\
\hline COEFFICIENTS & & & & -0.08655 & 1.18740 & 6.12506 & 0.71204 \\
\hline P-VALUE & & & & 0.98578 & 0.83778 & 0.35630 & 0.90048 \\
\hline
\end{tabular}


Table 12. Industrials, Cumulative Abnormal Returns with 5 days events windows

\begin{tabular}{|c|c|c|c|c|c|c|c|}
\hline 5 DAYS EVENT WINDOWS & CAR $(-15,-11)$ & $\operatorname{CAR}(-10,-6)$ & $\operatorname{CAR}(-5,-1)$ & $\operatorname{CAR}(0,4)$ & $\operatorname{CAR}(5,9)$ & CAR $(10,14)$ & $\operatorname{CAR}(15,19)$ \\
\hline \multicolumn{8}{|l|}{ CSS $(-20,-16)$} \\
\hline COEFFICIENTS & -1.25147 & 1.76959 & 18.90288 & 4.87131 & 17.74306 & -1.72617 & 1.83020 \\
\hline P-VALUE & 0.85616 & 0.82019 & 0.21495 & 0.40572 & $0.00097 * * *$ & 0.71206 & 0.64978 \\
\hline \multicolumn{8}{|l|}{$\operatorname{CSS}(-15,-11)$} \\
\hline COEFFICIENTS & & -1.75817 & 22.49485 & -3.26158 & 0.15427 & 1.02738 & 5.27752 \\
\hline P-VALUE & & 0.80635 & $0.09349 *$ & 0.53457 & 0.97612 & 0.80252 & 0.20815 \\
\hline \multicolumn{8}{|l|}{$\operatorname{CSS}(-10,-6)$} \\
\hline COEFFICIENTS & & & 33.28569 & -8.70365 & 0.83917 & 1.36601 & 4.32199 \\
\hline P-VALUE & & & $0.04113^{* *}$ & 0.17916 & 0.89514 & 0.78875 & 0.40134 \\
\hline \multicolumn{8}{|l|}{$\operatorname{CSS} 5(-5,-1)$} \\
\hline COEFFICIENTS & & & & 1.88037 & -5.03513 & 4.06636 & 6.24207 \\
\hline P-VALUE & & & & 0.81148 & 0.46447 & 0.52010 & 0.25392 \\
\hline
\end{tabular}

Table 13. Consumer Discretionary Industry, Cumulative Abnormal Returns with 5 days events windows

\begin{tabular}{|c|c|c|c|c|c|c|c|}
\hline 5 DAYS EVENT WINDOWS & CAR $(-15,-11)$ & CAR $(-10,-6)$ & $\operatorname{CAR}(-5,-1)$ & $\operatorname{CAR}(0,4)$ & $\operatorname{CAR}(5,9)$ & CAR $(10,14)$ & $\operatorname{CAR}(15,19)$ \\
\hline \multicolumn{8}{|l|}{$\operatorname{CSS}(-20,-16)$} \\
\hline COEFFICIENTS & -1.06951 & -3.50983 & 9.21589 & -1.96822 & 2.09278 & 1.72938 & 1.60009 \\
\hline P-VALUE & 0.87711 & 0.43634 & 0.41206 & 0.59222 & 0.72589 & 0.75668 & 0.62664 \\
\hline \multicolumn{8}{|l|}{$\operatorname{CSS}(-15,-11)$} \\
\hline COEFFICIENTS & & -3.24102 & 19.15955 & 1.24757 & 8.80686 & -4.64505 & -0.34024 \\
\hline P-VALUE & & 0.49656 & $0.01320 * *$ & 0.73402 & $0.09693^{*}$ & 0.36338 & 0.90931 \\
\hline \multicolumn{8}{|l|}{$\operatorname{CSS}(-10,-6)$} \\
\hline COEFFICIENTS & & & 12.10255 & 2.38648 & 6.43541 & -3.91520 & 3.37766 \\
\hline P-VALUE & & & 0.12872 & $0.09132 *$ & 0.24104 & 0.46419 & 0.27449 \\
\hline \multicolumn{8}{|l|}{$\operatorname{CSS} 5(-5,-1)$} \\
\hline COEFFICIENTS & & & & 2.90661 & -3.82403 & 6.60774 & 4.13122 \\
\hline P-VALUE & & & & $0.04894 * *$ & 0.57557 & 0.30316 & 0.27464 \\
\hline
\end{tabular}

Table 14. Consumer Staples Industry, Cumulative Abnormal Returns with 5 days events windows

\begin{tabular}{|c|c|c|c|c|c|c|c|}
\hline 5 DAYS EVENT WINDOWS & $\operatorname{CAR}(-15,-11)$ & CAR $(-10,-6)$ & $\operatorname{CAR}(-5,-1)$ & $\operatorname{CAR}(\mathbf{0 , 4})$ & $\operatorname{CAR}(5,9)$ & CAR $(10,14)$ & $\operatorname{CAR}(15,19)$ \\
\hline \multicolumn{8}{|l|}{ CSS $(-20,-16)$} \\
\hline COEFFICIENTS & 5.82225 & -4.49784 & -23.21912 & 12.88006 & 0.08706 & 0.83472 & -11.04534 \\
\hline P-VALUE & 0.63613 & 0.68667 & 0.22673 & 0.10443 & 0.99033 & $0.04228^{* *}$ & 0.27817 \\
\hline \multicolumn{8}{|l|}{ CSS $(-15,-11)$} \\
\hline COEFFICIENTS & & -1.96270 & 11.28643 & -3.29229 & 7.26935 & -4.98510 & 12.20448 \\
\hline P-VALUe & & 0.85919 & 0.46141 & 0.68230 & 0.32539 & 0.59833 & 0.24362 \\
\hline \multicolumn{8}{|l|}{$\operatorname{CSS}(-10,-6)$} \\
\hline COEFFICIENTS & & & 22.51320 & -3.49728 & -7.93191 & 0.17616 & 8.02544 \\
\hline P-VALUe & & & 0.21154 & 0.65327 & 0.36205 & 0.98181 & 0.43730 \\
\hline \multicolumn{8}{|l|}{$\operatorname{CSS} 5(-5,-1)$} \\
\hline COEFFICIENTS & & & & 2.53722 & -8.92460 & 12.82187 & 8.92670 \\
\hline P-VALUE & & & & 0.75987 & 0.25823 & 0.20947 & 0.41462 \\
\hline
\end{tabular}


Table 15. Health Care Industry, Cumulative Abnormal Returns with 5 days events windows

\begin{tabular}{|c|c|c|c|c|c|c|c|}
\hline 5 DAYS EVENT WINDOWS & CAR $(-15,-11)$ & CAR $(-10,-6)$ & $\operatorname{CAR}(-5,-1)$ & $\operatorname{CAR}(\mathbf{0 , 4})$ & $\operatorname{CAR}(5,9)$ & CAR $(10,14)$ & $\operatorname{CAR}(15,19)$ \\
\hline \multicolumn{8}{|l|}{$\operatorname{CSS}(-20,-16)$} \\
\hline COEFFICIENTS & -1.87984 & 6.33031 & 19.07428 & 4.85171 & -0.22115 & 1.78208 & -3.09800 \\
\hline P-VALUE & 0.30573 & 0.30364 & 0.11910 & 0.34932 & 0.97695 & 0.71834 & 0.60783 \\
\hline \multicolumn{8}{|l|}{$\operatorname{CSS}(-15,-11)$} \\
\hline COEFFICIENTS & & 0.30460 & 15.74866 & 4.13902 & -7.58451 & -6.41752 & -6.83619 \\
\hline P-VALUE & & 0.96320 & 0.23298 & 0.37180 & 0.31281 & 0.12745 & 0.24738 \\
\hline \multicolumn{8}{|l|}{$\operatorname{CSS}(-10,-6)$} \\
\hline COEFFICIENTS & & & -6.34938 & -1.86087 & 1.20538 & 1.45773 & 6.07923 \\
\hline P-VALUE & & & 0.61824 & 0.67857 & 0.86443 & 0.71430 & 0.28557 \\
\hline \multicolumn{8}{|l|}{$\operatorname{CSS} 5(-5,-1)$} \\
\hline COEFFICIENTS & & & & -6.32616 & -3.15752 & 8.92803 & 0.12918 \\
\hline P-VALUE & & & & 0.31841 & 0.73595 & 0.14401 & 0.98601 \\
\hline
\end{tabular}

Table 16. Financials Industry, Cumulative Abnormal Returns with 5 days events windows

\begin{tabular}{|c|c|c|c|c|c|c|c|}
\hline 5 DAYS EVENT WINDOWS & $\operatorname{CAR}(-15,-11)$ & $\operatorname{CAR}(-10,-6)$ & $\operatorname{CAR}(-5,-1)$ & CAR $(0,4)$ & $\operatorname{CAR}(5,9)$ & CAR $(10,14)$ & $\operatorname{CAR}(15,19)$ \\
\hline \multicolumn{8}{|l|}{$\operatorname{CSS}(-20,-16)$} \\
\hline COEFFICIENTS & -92.69352 & -204.45005 & 136.64024 & 1.82507 & 133.11757 & -33.03043 & -273.95785 \\
\hline P-VALUE & 0.55400 & 0.22058 & 0.59935 & 0.99095 & 0.55932 & 0.77600 & 0.19788 \\
\hline \multicolumn{8}{|l|}{$\operatorname{CSS}(-15,-11)$} \\
\hline COEFFICIENTS & & 1.68535 & -5.91147 & 2.86761 & -2.53238 & 7.98327 & 2.82939 \\
\hline P-VALUE & & 0.69087 & 0.37617 & 0.48121 & 0.63905 & $0.00525 * * *$ & 0.57761 \\
\hline \multicolumn{8}{|l|}{$\operatorname{CSS}(-10,-6)$} \\
\hline COEFFICIENTS & & & -1.52702 & 3.07165 & 0.65231 & 1.59080 & 2.84232 \\
\hline P-VALUE & & & 0.79158 & 0.42887 & 0.90152 & 0.55944 & 0.57122 \\
\hline \multicolumn{8}{|l|}{$\operatorname{CSS} 5(-5,-1)$} \\
\hline COEFFICIENTS & & & & 6.21024 & -2.99225 & 2.55942 & 8.64675 \\
\hline P-VALUE & & & & 0.10889 & 0.58219 & 0.35664 & $0.08980^{*}$ \\
\hline
\end{tabular}

Table 17. Information Technology Industry, Cumulative Abnormal Returns with 5 days events windows

\begin{tabular}{|c|c|c|c|c|c|c|c|}
\hline 5 DAYS EVENT WINDOWS & CAR $(-15,-11)$ & CAR $(-10,-6)$ & $\operatorname{CAR}(-5,-1)$ & CAR $(\mathbf{0 , 4})$ & $\operatorname{CAR}(5,9)$ & CAR $(10,14)$ & $\operatorname{CAR}(15,19)$ \\
\hline \multicolumn{8}{|l|}{ CSS (-20,-16) } \\
\hline COEFFICIENTS & 4.17536 & -3.69748 & 12.03857 & 1.73303 & 4.48566 & 4.07201 & -0.98082 \\
\hline P-VALUE & 0.37999 & 0.27630 & 0.14465 & 0.72349 & 0.38626 & 0.18558 & 0.69010 \\
\hline \multicolumn{8}{|l|}{ CSS $(-15,-11)$} \\
\hline COEFFICIENTS & & 1.11276 & 7.16108 & -0.12028 & 3.09131 & -1.65646 & -0.25918 \\
\hline P-VALUE & & 0.68194 & 0.30044 & 0.97663 & 0.42574 & 0.49561 & 0.89182 \\
\hline \multicolumn{8}{|l|}{ CSS (-10,-6) } \\
\hline COEFFICIENTS & & & -5.79184 & 4.39477 & -2.64954 & 3.94385 & 1.04186 \\
\hline P-VALUE & & & 0.47129 & 0.29965 & 0.51013 & $0.09371^{*}$ & 0.55078 \\
\hline \multicolumn{8}{|l|}{$\operatorname{CSS} 5(-5,-1)$} \\
\hline COEFFICIENTS & & & & 3.06487 & 0.32378 & -0.13798 & 1.52841 \\
\hline P-VALUE & & & & $0.04711^{* *}$ & 0.94224 & 0.95834 & 0.47420 \\
\hline
\end{tabular}


Table 18. Telecommunications Industry, Cumulative Abnormal Returns with 5 days events windows

\begin{tabular}{|c|c|c|c|c|c|c|c|}
\hline 5 DAYS EVENT WINDOWS & $\operatorname{CAR}(-15,-11)$ & CAR $(-10,-6)$ & $\operatorname{CAR}(-5,-1)$ & $\operatorname{CAR}(0,4)$ & $\operatorname{CAR}(5,9)$ & CAR $(10,14)$ & $\operatorname{CAR}(15,19)$ \\
\hline \multicolumn{8}{|l|}{$\operatorname{CSS}(-20,-16)$} \\
\hline COEFFICIENTS & 7.83572 & -24.08951 & -6.15275 & 2.56128 & -14.10711 & -3.98226 & 5.73029 \\
\hline P-VALUe & 0.46872 & 0.48085 & 0.83008 & $0.09106^{*}$ & 0.46150 & $0.04473 * *$ & $0.08400^{*}$ \\
\hline \multicolumn{8}{|l|}{$\operatorname{CSS}(-15,-11)$} \\
\hline COEFFICIENTS & & 39.62051 & -18.15560 & -9.48710 & -0.28770 & -11.66911 & -0.03148 \\
\hline P-VALUE & & 0.19123 & 0.29770 & 0.19096 & 0.98525 & $0.09677 *$ & 0.99617 \\
\hline \multicolumn{8}{|l|}{ CSS $(-10,-6)$} \\
\hline COEFFICIENTS & & & -41.51015 & 1.60807 & 37.45486 & -13.45037 & 5.25555 \\
\hline P-VALUE & & & 0.11412 & 0.75801 & 0.15512 & $0.08810^{*}$ & 0.45056 \\
\hline \multicolumn{8}{|l|}{$\operatorname{CSS} 5(-5,-1)$} \\
\hline COEFFICIENTS & & & & -28.83479 & -9.94235 & 23.70553 & 42.78691 \\
\hline P-VALUE & & & & 0.45167 & 0.86001 & 0.55927 & 0.49664 \\
\hline \multicolumn{8}{|c|}{ Table 19. Utilities Industry, Cumulative Abnormal Returns with 5 days events windows } \\
\hline 5 DAYS EVENT WINDOWS & $\operatorname{CAR}(-15,-11)$ & CAR $(-10,-6)$ & $\operatorname{CAR}(-5,-1)$ & CAR $(0,4)$ & CAR(5,9) & CAR $(10,14)$ & CAR(15,19) \\
\hline \multicolumn{8}{|l|}{$\operatorname{CSS}(-20,-16)$} \\
\hline COEFFICIENTS & 11.33852 & 2.59923 & -24.24822 & 9.72455 & -17.41664 & -15.69374 & 30.93241 \\
\hline P-VALUE & 0.45621 & 0.71312 & 0.18452 & 0.36552 & 0.28565 & 0.26427 & 0.11755 \\
\hline \multicolumn{8}{|l|}{$\operatorname{CSS}(-15,-11)$} \\
\hline COEFFICIENTS & & -22.38879 & -28.49785 & 29.71203 & -15.69177 & -3.02279 & -9.71625 \\
\hline P-VALUE & & 0.15896 & 0.34244 & 0.15657 & 0.55649 & 0.87865 & 0.74224 \\
\hline \multicolumn{8}{|l|}{$\operatorname{CSS}(-10,-6)$} \\
\hline COEFFICIENTS & & & 9.48305 & 12.16635 & -18.25392 & 11.76476 & -16.37519 \\
\hline P-VALUE & & & 0.72826 & 0.32446 & 0.29607 & 0.43273 & 0.39388 \\
\hline \multicolumn{8}{|l|}{$\operatorname{CSS} 5(-5,-1)$} \\
\hline COEFFICIENTS & & & & 8.55049 & -13.94506 & 15.46019 & -13.85024 \\
\hline P-VALUE & & & & 0.46447 & 0.43085 & 0.31223 & 0.51245 \\
\hline
\end{tabular}

\section{Conclusions}

Previous research literature have indicated that the equity related trading markets had a higher possibility of generating informed trading during the periods right before and after earnings announcements. Among different kinds of information based traders, the presence short sellers have been found in different empirical studies that test for them. The majority of these studies have found that short sellers have the best ability to estimate more accurately the correct stock price based on public information disclosed by firms. Short sellers have also demonstrated their superior ability to adjust their trading positions in order to gain optimal returns.

Prior studies indicate that there are different levels of investor sophistication. These different levels of investor sophistication result in different interpretations of results of earnings announcements as well as different interpretations of future earnings announcements. Investors that are less sophisticated tend to invest superficially because they do not have the proper knowledge or resources to invest based on fundamentals. Sophisticated investors, or informed traders, know that there exist these unsophisticated investors, therefore when given the opportunity, sophisticated investors will take advantage of divergent asset prices and adjust the prices back to fundamental prices.

Unsophisticated investors will sometimes rely on different resources for analysis of the fundamental values of different assets. These resources are in the form of financial analysts. Previous literatures have documented the effects of analyst recommendation on stock returns, specifically when analysts raise target prices of stocks. We can 
see an abnormal rise in the stock price converging substantially to the analysts target price. On the flip side, when analysis lower the target price of stocks, we see that prices fall, again, converging substantially to the analysts target price.

It is important to note that informed traders in our study are not analysts; they are individual investors that are sophisticated and have superior investment knowledge, above analysts in some cases. These informed traders will not engage in speculative trading, but will only trade if they see an opportunity for arbitrage. Naturally, informed traders have an incentive to keep their superior knowledge to themselves and not reveal what they know to outsiders, as this will prevent them from taking advantage of arbitrage.

During actual trading, the levels of investment sophistication are not known across the market; therefore, the only way to distinguish levels of sophistication is by looking at actual trading behaviors. According to different literatures, unsophisticated investors tend more to trade through long positions (i.e. buying stocks) than short positions. Sophisticated investors tend to engage in both long and short (i.e. selling of stocks that they do not own) positions. Knowing this, we can see that if we have short selling, then we can safely assume that these short sellers are sophisticated investors, and therefore, use this as a proxy to distinguish between sophisticated and non-sophisticated investors.

Unsophisticated investors, as we mentioned before, will likely invest based on analysts' recommendations, firm recommendations, or they might just invest based on a 'gut feeling'. When firms announce earnings for the previous quarter it is standard that they also announce forward looking numbers as well. When analysts seek to publish expect firm performance expectations, they usually do so throughout the quarter at random times. Therefore, as unsophisticated investors seek to guidance on stocks, they would rather wait to see what either the analysts or the firm say about future earnings expectations to base their investment strategy upon.

Investors will know the success of their investment by means of the announcement of earnings by the firm itself every quarter. Thereafter, given the efficiency of the market, if aggregate investor expectations and analyst/firm expectations are inline (no surprise), then we should not see a significant/abnormal change in stock returns. Assuming that unsophisticated investors buy and sell based on analyst and firm recommendations before the earnings announcement, if we get a positive surprise in the earnings, then we might see some, but not much, significant/abnormal change in stock returns [we say some abnormal change in stock returns as per noted in previous studies]. However, if sophisticated investors expect that firm/analyst numbers are not accurate, and that the firms' actual numbers are much less than the expected numbers; then they would arbitrage and short the stocks, resulting in abnormal returns in the underlying stocks.

Looking at our results, we can see that they are closely aligned with previous studies. Informed traders do have the ability to achieve abnormal returns in the stock market. By looking at the degree to which the stock is shorted, we can see that short sellers (informed traders) do take advantage of overpriced stocks, and do short stocks before earnings announcement (or the confirmation of past expectations of future cash flows). We further distinguished between positive and negative SUE (positive surprise in earnings, and negative surprise in earnings respectively) and find that there were more instances of cumulative abnormal returns with negative SUE than with positive. This indicates that short sellers are more likely to take advantage of overpriced stocks, using a tool (shorting) that is not traditionally used by unsophisticated investors.

What's more, we find further evidence that informed traders also follow stock analysts not for investing advice, but to take advantage of those unsophisticated investors that buy in, if you will, to the rhetoric expressed by financial analysts. We consider this as a unique finding that past studies have not considered. Look at both sides of the wall we can see that owners want prices to increase, and fear any price decrease. On the flip side, non-owners want to buy, but for a bargain price, as to eke out a profit as best they can. Yet, when we include short sellers in to the market, we can see that the entire situation changes. The notion of buy low to sell high in order to make a profit has transformed to sell high and buy low to make a profit. This interesting point of view is not natural, as one may believe, because it leads to the question of, how can you sell something that you do not own. This research looks at those individuals with the audacity to defy what is naturally believed to be the correct way to behave, and turn it on its head. Those who possess this audacity are what we consider sophisticated - having superior knowledge - informed traders. We specifically know that when assets are overpriced, those who bring down the price towards fundamentals are short sellers. If short sellers are informed traders, they possess private information that can be used to gain an advantage over others. 


\section{References}

Asquith, P., Pathak, P. A., \& Ritter, J. R. (2005). Short interest, institutional ownership, and stock returns. Journal of Financial Economics, 78(2), 243-276. https://doi.org/10.1016/j.jfineco.2005.01.001

Back, K. (1993). Asymmetric information and options. Review of Financial Studies, 6(3), 435-472. https://doi.org/10.1093/rfs/5.3.435

Ball, R., \& Bartov, E. (1996). How naive is the stock market's use of earnings information? Journal of Accounting and Economics, 21(3), 319-337.

Bernard, V. \& Thomas, J. (1990). Evidence that stock prices do not fully reflect the implications of current earnings for future earnings. Journal of Accounting and Economics, 13(4), 305-340. https://doi.org/10.1016/0165-4101(90)90008-R

Biais, B., \& Hillion, P. (1994). Insider and liquidity trading in stock and options markets. Review of Financial Studies, 7(4). 743-780. https://doi.org/10.1093/rfs/7.4.743

Black, F. (1975). Fact and Fantasy in the Use of Options. Financial Analysts Journal, 31(4), 36-72. https://doi.org/10.2469/faj.v31.n4.36

Bloomfield, R., \& Hales, J. (2002). Predicting the next step of a random walk: Experimental evidence of regime-shifting beliefs. Journal of Financial Economics, 65(3), 397-414. https://doi.org/10.1016/S0304-405X(02)00147-2

Boehme, R. D., Danielsen, B. R., \& Sorescu, S. M. (2006). Short-Sale Constraints, Differences of Opinion, and Overvaluation. Journal of Financial \& Quantitative Analysis, 41(2), 455-487. https://doi.org/10.1017/S0022109000002143

Boehmer, E., Jones, C. M., \& Zhang, X. (2008). Which Shorts Are Informed? Journal of Finance, 63(2), 491-527.

Brunnermeier, M. K. (2001). Asset Pricing under Asymmetric Information: Bubbles, Crashes, Technical Analysis, and Herding (First ed.) U.K.: Oxford University Press. https://doi.org/10.1093/0198296983.001.0001

Chen, J., Hong, H., \& Stein, J. C. (2002). Breadth of ownership and stock returns. Journal of Financial Economics, 66(2-3), 171-205. https://doi.org/10.1016/S0304-405X(02)00223-4

Christophe, S. E., Ferri, M. G., \& Angel, J. J. (2004). Short-Selling Prior to Earnings Announcements. Journal of Finance, 59(4), 1845-1875. https://doi.org/10.1111/j.1540-6261.2004.00681.x

Cohen, L., Diether, K. B., \& Malloy, C. J. (2007). Supply and Demand Shifts in the Shorting Market. Journal of Finance, 62(5), 2061-2096. https://doi.org/10.1111/j.1540-6261.2007.01269.x

Daniel, K. D., Hirshleifer, D., \& Subrahmanyam, A. (2001). Overconfidence, Arbitrage, and Equilibrium Asset Pricing. Journal of Finance, 56(3), 921-965. https://doi.org/10.1111/0022-1082.00350

D'Avolio, G. (2002). The market for borrowing stock. Journal of Financial Economics, 66(2-3), 271-306. https://doi.org/10.1016/S0304-405X(02)00206-4

Desai, H., Ramesh, K., Thiagarajan, S. R., \& Balachandran, B. V. (2002). An Investigation of the Informational Role of Short Interest in the NASDAQ Market. Journal of Finance, 57(5), 2263-2287. https://doi.org/10.1111/0022-1082.00495

Diether, K. B., Lee, K.-H., \& Werner, I. M. (2009). Short-Sale Strategies and Return Predictability. Review of Financial Studies, 22(2), 575-607. https://doi.org/10.1093/rfs/hhn047

Fama, E. F., \& French, K. R. (1993). Common risk factors in the returns on stocks and bonds. Journal of Financial Economics, 33(1), 3-56. https://doi.org/10.1016/0304-405X(93)90023-5

Gruber, M. J. (1996). Another Puzzle: The Growth in Actively Managed Mutual Funds. Journal of Finance, 51(3), 783-810. https://doi.org/10.1111/j.1540-6261.1996.tb02707.x

Henry, T. R., \& Koski, J. L. (2010). Short Selling Around Seasoned Equity Offerings. Review of Financial Studies, 23(12), 4389-4418. https://doi.org/10.1093/rfs/hhq076

IOSCO. (2008). Technical Committee Members' Initiatives Relating to Restrictions on Short Sales. Retrieved 21 March 2011.

Jones, C. M., \& Lamont, O. A. (2002). Short-sale constraints and stock returns. Journal of Financial Economics, 66(2-3), 207-239. https://doi.org/10.1016/S0304-405X(02)00224-6 
Kang, J., Liu, M.-H., \& Ni, S. X. (2002). Contrarian and momentum strategies in the China stock market: 1993-2000. Pacific-Basin Finance Journal, 10(3), 243-265. https://doi.org/10.1016/S0927-538X(02)00046-X

Lamont, O. A., \& Stein, J. C. (2004). Aggregate Short Interest and Market Valuations. American Economic Review, 94(2), 29-32. https://doi.org/10.1257/0002828041301759

Lecce, S., Lepone, A., McKenzie, M., \& Segara, R. (2012). The impact of naked short selling on the securities lending and equity market. Journal of Financial Markets, 15(1), 81-107. https://doi.org/10.1016/j.finmar.2011.07.001

MacKinlay, A. C. (1997). Event Studies in Economics and Finance. Journal of Economic Literature, 35(1), 13-39.

Manaster, S., \& Rendleman, J. R. J. (1982). Option Prices as Predictors of Equilibrium Stock Prices. Journal of Finance, 37(4), 1043-1057. https://doi.org/10.1111/j.1540-6261.1982.tb03597.x

Montier, J. (2002). Behavioural Finance: Insights into Irrational Minds and Markets (First ed.) N.Y. : Wiley.

Nagel, S. (2005). Short sales, institutional investors and the cross-section of stock returns. Journal of Financial Economics, 78(2), 277-309. https://doi.org/10.1016/j.jfineco.2004.08.008

Poteshman, A. M. (2001). Underreaction, Overreaction, and Increasing Misreaction to Information in the Options Market. Journal of Finance, 56(3), 851-876. https://doi.org/10.1111/0022-1082.00348

Roll, R., Schwartz, E., \& Subrahmanyam, A. (2010). O/S: The relative trading activity in options and stock. Journal of Financial Economics, 96(1), 1-17. https://doi.org/10.1016/j.jfineco.2009.11.004

Sadka, R. (2006). Momentum and post-earnings-announcement drift anomalies: The role of liquidity risk. Journal of Financial Economics, 80(2), 309-349. https://doi.org/10.1016/j.jfineco.2005.04.005

Skinner, D. J. (1990). Options markets and the information content of accounting earnings releases. Journal of Accounting and Economics, 13(3), 191-211. https://doi.org/10.1016/0165-4101(90)90031-X

Takahashi, H. (2010). Short-sale inflow and stock returns: Evidence from Japan. Journal of Banking \& Finance, 34(10), 2403-2412. https://doi.org/10.1016/j.jbankfin.2010.03.001

Theobald, M., \& Yallup, P. (2004). Determining security speed of adjustment coefficients. Journal of Financial Markets, 7(1), 75-96. https://doi.org/10.1016/S1386-4181(02)00068-X

Thomson, M. E., Önkal-Atay, D., Pollock, A. C., \& Macaulay, A. (2003). The influence of trend strength on directional probabilistic currency predictions. International Journal of Forecasting, 19(2), 241-256. https://doi.org/10.1016/S0169-2070(01)00132-7

Wermers, R. (2000). Mutual Fund Performance: An Empirical Decomposition into Stock-Picking Talent Style. Journal of Finance, 55(4), 1655-1695. https://doi.org/10.1111/0022-1082.00263 